Original paper

\title{
Molybdenite-tungstenite association in the tungsten-bearing topaz greisen at Vítkov (Krkonoše-Jizera Crystalline Complex, Bohemian Massif): indication of changes in physico-chemical conditions in mineralizing system
}

\author{
Jan PAŠAVA ${ }^{1 *}$, František VESELOVSKÝ ${ }^{1}$, Milan DRÁBEK ${ }^{1}$, Martin SVOJTKA ${ }^{2}$, Ondřej POUR ${ }^{1}$, \\ Josef KLOMÍNSKÝ1, Radek ŠKODA' ${ }^{1}$, Jana ĎURIŠOVÁ², Lukáš ACKERMAN², Patricie \\ HALODOVÁ ${ }^{\text {, Eva HALUZOVÁ }}$
}

\author{
${ }^{1}$ Czech Geological Survey, Klárov 3/131, 11821 Prague 1, Czech Republic; jan.pasava@geology.cz \\ ${ }^{2}$ Institute of Geology of the Czech Academy of Sciences v.v.i., Rozvojová 269, 16500 Prague 6, Czech Republic \\ * Corresponding author
}

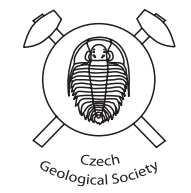

\begin{abstract}
At Vítkov, sparse molybdenite occurs within tungsten mineralization hosted by topaz greisen in orthogneiss in the envelope of the Variscan Krkonoše-Jizera granite Pluton (northern Bohemian Massif). Mineralogical study showed that sulfide mineralization started with precipitation of arsenopyrite followed by molybdenite, tungstenite, transitional Mo- and W-dominated disulfides and concluded by pyrite. Textural relationships between molybdenite and tungstenite imply that tungstenite was formed during several stages related to molybdenite bending and fracturing. Laser Ablation Inductively Coupled Mass Spectrometry (LA-ICP-MS) analyses of Re-poor $(<0.3 \mathrm{ppm})$ molybdenite showed extreme concentrations of W (up to $26558 \mathrm{ppm}$ ) accompanied by Ag, As, $\mathrm{Bi}, \mathrm{Pb}, \mathrm{Se}$, Te and other metals. Electron microprobe analyses of inclusions-free molybdenite confirmed the abundance of W ( $\sim 0.5$ wt. $\%)$ and tungstenite showed $\sim 4$ wt. $\%$ $\mathrm{Mo}$, indicating a substitution of $\mathrm{Mo}^{4+}$ for $\mathrm{W}^{4+}$. Stability and phase relationships between molybdenite and tungstenite and locally identified transitional Mo- and W-dominated disulfidic phases suggest that tungstenite crystallization was triggered by a decrease in $\mathrm{fO}_{2}$ below $\mathrm{WO}_{2}-\mathrm{WO}_{3}$ buffer that followed after molybdenite precipitation. Tungstenite zoning and sharp tungstenite-molybdenite contacts indicate disequilibrium during their formation.
\end{abstract}

Keywords: LA-ICP-MS, EMPA, molybdenite, tungstenite, transitional Mo-W and $W$-Mo disulfides, Bohemian Massif Received: 12 June, 2015; accepted: 17 September, 2015; handling editor: M. Štemprok

\section{Introduction}

It was documented by many authors (e.g. Cook et al. 2009, 2013; Large et al. 2009, 2014; Sung et al. 2009; Lin et al. 2011; Thomas et al. 2011; Pašava et al. 2013, 2015, 2016) that Electron Microprobe Analysis (EMPA) and Laser Ablation Inductively Coupled Mass Spectroscopy (LA-ICP-MS) spot analyses and mapping are very useful for documentation and interpretation of trends of trace-element distribution in sulfides such as pyrite, arsenopyrite and sphalerite. Blevin and Jackson (1998) used LA-ICP-MS to measure a number of elements in molybdenite containing both Bi-mineral inclusions and $\mathrm{Au}$. They evidenced presence of $\mathrm{Pb}, \mathrm{Bi}$, Te and other elements and suggested for the first time that variation in their abundance could potentially be a valuable petrogenetic tool. This outcome was supported by Norman et al. (2004) who highlighted the importance of molybdenite trace-element data, notably $\mathrm{Bi}$, for fingerprinting mineralization in granitic settings. Recently, Ciobanu et al. (2013), confirmed the usefulness of this kind of study for identification of discrete events in young magmatic-hydrothermal systems on example of two $\mathrm{Au}$ and $\mathrm{Au}-\mathrm{Cu}-(\mathrm{Mo})$ porphyry-style deposits.

As an important carrier of Re, molybdenite has been proven to be a useful mineral in Re-Os geochronology (Stein et al. 2001). The method yields an age of mineralization and it is robust with respect to subsequent overprinting (e.g. Stein et al. 2003; Selby and Creaser 2004) except when subject to supergene alteration (McCandless et al. 1993). However, Košler et al. (2003) have documented heterogeneity within single grains of molybdenite caused most likely by decoupling of Re and Os which could, in turn, affect the accuracy of Re-Os ages. They suggested the need for homogenization of substantial quantities of molybdenite to capture the bulk Os/Re of the sample.

The Bohemian Massif is known for numerous Variscan $\mathrm{Au}, \mathrm{Sn}-\mathrm{W}, \mathrm{U}$ and base-metal deposits located in different geotectonic units and settings. These mineralizations are sometimes accompanied by molybdenite, which is much more widespread in granite-related ore deposits (Drábek 
et al. 1993). No tungstenite was ever reported from this type of deposits in the Bohemian Massif. First study on chemistry of Re and Se in molybdenite in the Bohemian Massif was carried out by Kvaček and Trdlička (1970) and followed by Kvaček et al. (1983), and Drábek et al. (1989 and 1993). Košler et al. (2003) reported inhomogeneously distributed Re in molybdenite from several gold deposits in the Bohemian Massif.

In this paper we present new mineralogical, LAICP-MS and EMPA data for Re-poor molybdenite and associated transitional $\mathrm{W}-\mathrm{Mo} / \mathrm{Mo}-\mathrm{W}$ disulfides from Vítkov (Krkonoše-Jizera Crystalline Complex, Bohemian Massif). We demonstrate how different physico-chemical conditions during mineralizing processes are reflected by chemical composition of molybdenite and related sulfides and also by the presence of impurities in molybdenite.

\section{Geological setting and mineralization}

Topaz-bearing greisens belong to exotic rocks in the West Sudetes domain which is mostly considered a part of the Saxothuringian Zone (e.g. Kosmat 1927; Behr et al. 1984; Franke et al. 1993; Mikulski and Stein 2011; Mochnacka et al. 2015) of the Bohemian Massif located at the eastern termination of the European Variscan Belt (Fig. 1a). The West Sudetes in the northern margin of the Bohemian Massif (Fig. 1a) are composed of a heterogeneous mo-

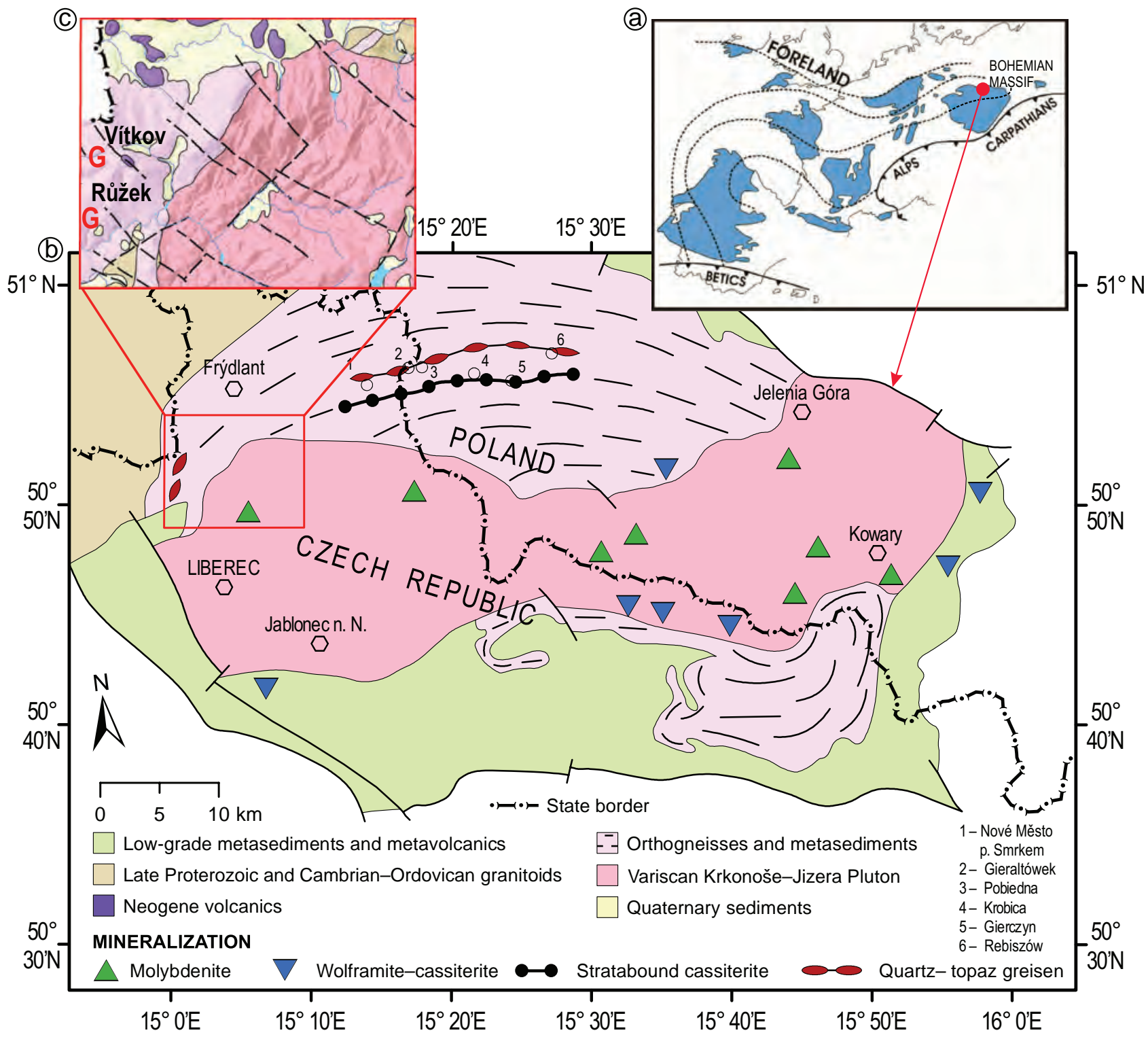

Fig. 1a - Position of the Bohemian Massif and major tectonostratigraphic zones of the Variscan orogenic belt in Europe. b - Simplified geological map of the Krkonoše-Jizera Pluton within the West Sudetes crystalline complexes (adapted from Chrt et al. 1968); associated mineral deposits and occurrences are also shown. c - Detailed geological map of the Vítkov and Rủžek quartz-topaz greisen localities. 
saic of pre-Permian basement fragments comprising the Krkonoše-Jizera orthogneisses representing deformed and metamorphosed granitoids of the Lusatian Batholith of Late Proterozoic up to Ordovician age (Kozlowska 1956; Karwowski 1973) and Neoproterozoic to Lower Paleozoic low-grade metamorphic complex dominated by phyllites, and metavolcanic rocks (Kachlík and Patočka 1998). In the middle of these heterogeneous rock assemblages is situated the Krkonoše-Jizera granite Pluton (Fig. 1b) of Variscan age (Žák et al. 2013). Before the Krkonoše-Jizera granite Pluton emplacement, the Variscan tectonic history of these rocks involved oceanic subduction and blueschist-facies metamorphism dated at around $360 \mathrm{Ma}$, followed by collision, nappe stacking and widespread greenschist-facies metamorphism at around 340 Ma (Maluski and Patočka 1997; Faryad and Kachlík 2010).

Biotite and two-mica orthogneisses are strongly foliated rocks that were probably the parental material of the locally intensely metasomatized rocks containing quartz and topaz with white mica, tourmaline, traces of sulfides (molybdenite and arsenopyrite), wolframite and cassiterite (Karwowski 1973 and 1977). Similar mineral association is known from the interior of the KrkonošeJizera granite Pluton (Fig. 1b).

Stratabound quartz-topaz greisen bodies are located on both sites of the Polish-Czech border (Fig. 1b). In Poland, quartz-topaz greisens occur between leucogranites and mica schists between Rębiszów and Gierałtówek settlements (Mlądz-Kamień-Pobiedna Zone, Karwowski 1973, 1977). It is a narrow E-W trending zone, about a hundred meters wide and more than $10 \mathrm{~km}$ long, parallel to well-known strata-bound Nové Město p. Smrkem-Gierczyn-Krobica Variscan tin mineralization (Fig. 1b).

On the Czech territory, similar greisens were found near Růžek and Vítkov settlements (Watzernauer 1940; Klomínský et al. 2003; Vondrovic et al. 2015; Fig. 1c). On the both sides of the Polish-Czech border, the only remnants of the former outcrops are loose greisen blocks that occur parallel to other geological structures (metamorphic foliation) of the Krkonoše-Jizera orthogneisses, 3-10 km away from the Krkonoše-Jizera Pluton's northern margin (Fig. 1b). At Vítkov, dominant wolframite (ferberite) accompanied by accessoric scheelite, pyrite, molybdenite, arsenopyrite, native bismuth, rutile (with increased $\mathrm{Nb}$ and $\mathrm{Ta}$ ) and zircon was reported by Sidorinová and Dobeš (in print).

\section{Methods}

We prepared polished sections from selected mineralized samples containing rather rare molybdenite and then used field-emission scanning electron microscope Tescan Mira3 GMU fitted with energy-dispersive spectrometer Oxford Instruments X-Max $80\left(80 \mathrm{~mm}^{2}\right.$ active area $)$ at the Czech Geological Survey for more detailed mineralogical study. Quant optimization was performed on the cobalt standard. Synthetic factory standards were used ( $\mathrm{FeS}_{2}$ for S, metallic Mo and metallic W) for qualitative analysis. Analytical conditions during the analysis were $7 \mathrm{nA}$ absorbed current at an accelerating voltage of $20 \mathrm{kV}$. Analytical results were processed in the AZtec software version 3.0 (Oxford Instruments).

The molybdenite trace-element data were obtained using an Element 2 high-resolution ICP-MS coupled with a 213-nm NdYAG UP-213 laser-ablation system at the Institute of Geology of the Czech Academy of Sciences, v.v.i. The following isotopes were measured at the two mass-resolution modes in order to avoid isobaric and polyatomic interferences: (1) the low mass-resolution mode $(\mathrm{m} / \Delta \mathrm{m}=300)$ was used for ${ }^{57} \mathrm{Fe},{ }^{75} \mathrm{As},{ }^{77} \mathrm{Se},{ }^{90} \mathrm{Zr}$, ${ }^{93} \mathrm{Nb},{ }^{107} \mathrm{Ag},{ }^{118} \mathrm{Sn},{ }^{121} \mathrm{Sb},{ }^{125} \mathrm{Te},{ }^{182} \mathrm{~W},{ }^{187} \mathrm{Re},{ }^{197} \mathrm{Au},{ }^{208} \mathrm{~Pb}$ and ${ }^{209} \mathrm{Bi}$, while (2) medium-resolution $(\mathrm{m} / \Delta \mathrm{m}=4000)$ mode was required for ${ }^{56} \mathrm{Fe},{ }^{59} \mathrm{Co},{ }^{60} \mathrm{Ni},{ }^{63} \mathrm{Cu}$ and ${ }^{66} \mathrm{Zn}$. More detailed description of the method was given in Pašava et al. (2016).

Electron-microprobe analyses (EMPA) were performed on the Cameca SX-100 instrument at the Joint Laboratory of Electron Microscopy and Microanalysis of the Masaryk University and the Czech Geological Survey (Brno, Czech Republic). The measurements were carried out using a wave-dispersion mode under the following conditions: accelerating voltage of $25 \mathrm{kV}$, beam current of $20 \mathrm{nA}$ and the beam diameter of $1 \mu \mathrm{m}$. Natural and synthetic standards were employed $\left(\mathrm{FeS}_{2}\right.$ for $\mathrm{Fe}$ and $\mathrm{S}$, pararammelsbergite for $\mathrm{Ni}$ and $\mathrm{As}$, with metallic $\mathrm{Co}$, $\mathrm{Mo}, \mathrm{W}$ and $\mathrm{Re}$ ). Used lines were: $\mathrm{K}_{\alpha}$ for $\mathrm{Co}, \mathrm{Fe}, \mathrm{Ni}$ and $S, L_{\alpha}$ for Re and $W$, and $L_{\beta}$ for As and Mo. For molybdenite, peak count times were $20 \mathrm{~s}$ for Mo, W and S, and $120 \mathrm{~s}$ for Re. Background count times were $10 \mathrm{~s}$ for Mo and W, $20 \mathrm{~s}$ for $\mathrm{S}$ and $60 \mathrm{~s}$ for Re. For arsenopyrite, count times were $20 \mathrm{~s}$ on peak ( $\mathrm{Fe}, \mathrm{Co}, \mathrm{Ni}, \mathrm{As}$ and $\mathrm{S})$ and $10 \mathrm{~s}$ on background.

\section{Results}

\subsection{Mineralogy of major sulfides}

Molybdenite in analyzed sample from greisen-type mineralization at Vítkov occurs mostly as fine- to mediumgrained, lamellar aggregates or fragments of lamellae with common kinks and bending (Fig. 2a). Molybdenite is younger than arsenopyrite (Fig. 2a). Similarly, tungstenite is younger than arsenopyrite and molybdenite. It forms nano- to micron-sized inter-lamellar fillings in 

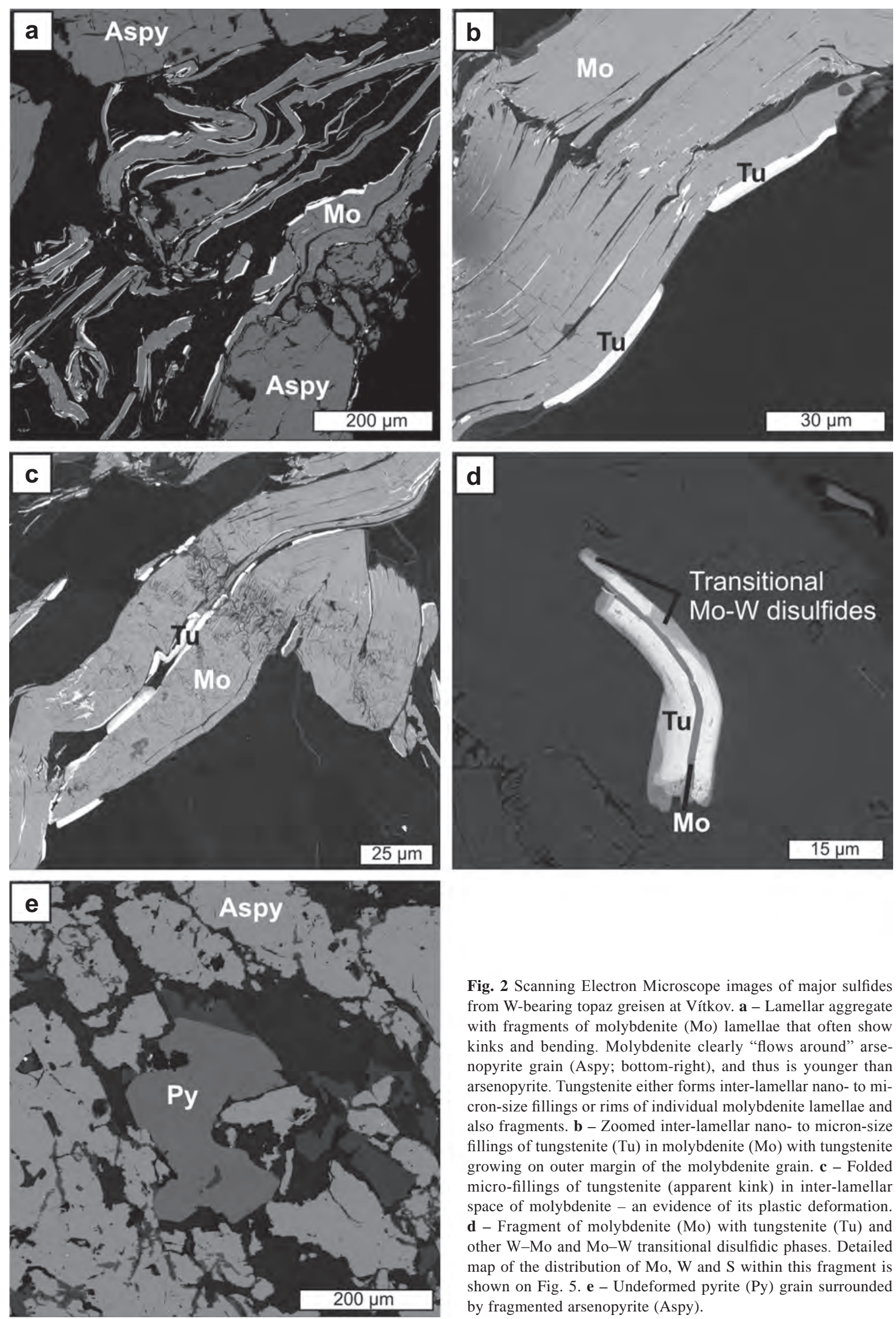

Fig. 2 Scanning Electron Microscope images of major sulfides from W-bearing topaz greisen at Vítkov. a - Lamellar aggregate with fragments of molybdenite (Mo) lamellae that often show kinks and bending. Molybdenite clearly "flows around" arsenopyrite grain (Aspy; bottom-right), and thus is younger than arsenopyrite. Tungstenite either forms inter-lamellar nano- to micron-size fillings or rims of individual molybdenite lamellae and also fragments. $\mathbf{b}$ - Zoomed inter-lamellar nano- to micron-size fillings of tungstenite ( $\mathrm{Tu}$ ) in molybdenite (Mo) with tungstenite growing on outer margin of the molybdenite grain. c - Folded micro-fillings of tungstenite (apparent kink) in inter-lamellar space of molybdenite - an evidence of its plastic deformation. d - Fragment of molybdenite (Mo) with tungstenite (Tu) and other $\mathrm{W}-\mathrm{Mo}$ and $\mathrm{Mo}-\mathrm{W}$ transitional disulfidic phases. Detailed map of the distribution of Mo, $\mathrm{W}$ and $\mathrm{S}$ within this fragment is shown on Fig. 5. e - Undeformed pyrite (Py) grain surrounded by fragmented arsenopyrite (Aspy). 
Tab. 1 LA-ICP-MS spot analyses in molybdenite from W-mineralization hosted by Vítkov topaz greisen (ppm)

\begin{tabular}{|c|c|c|c|c|c|c|c|c|c|c|c|c|c|c|c|c|c|c|}
\hline $\begin{array}{l}\text { Sample } \\
\text { grain size }\end{array}$ & & Co & $\mathbf{N i}$ & $\mathrm{Cu}$ & Zn & As & Se & $\mathrm{Zr}$ & Nb & Ag & Sn & Sb & $\mathrm{Te}$ & $\mathbf{W}$ & $\mathbf{R e}$ & Au & $\mathbf{P b}$ & $\mathbf{B i}$ \\
\hline & *IDL $55 \mu m$ & 0.2 & 22 & 0.5 & 0.5 & 0.5 & 1.5 & 0.07 & 0.10 & 0.04 & 0.3 & 0.05 & 0.4 & 0.10 & 0.03 & 0.01 & 0.0 & 0.03 \\
\hline Vítkov & fibrous fragment & 42 & $<\mathrm{IDL}$ & 33 & 7.2 & 1774 & 211 & 3.4 & 6.5 & 37 & 5.3 & 6.8 & 3.8 & 26558 & $<$ IDL & 1.26 & 90 & 639 \\
\hline VIT-1 & fibrous fragment & 32 & $<$ IDL & 29 & 4.6 & 2232 & 290 & 2.1 & 1.9 & 32 & $<$ IDL & 3.0 & 2.1 & 6286 & $<$ IDL & 0.73 & 61 & 127 \\
\hline \multirow[t]{9}{*}{$55 \mu \mathrm{m}$} & fibrous fragment & 0.38 & $<\mathrm{IDL}$ & 21 & 3.5 & 1112 & 293 & 0.13 & 0.33 & 3.8 & $<\mathrm{IDL}$ & 0.40 & 3.8 & 330 & $<$ IDL & 0.11 & 3.6 & 37 \\
\hline & fibrous fragment & 10 & $<\mathrm{IDL}$ & 17 & 3.2 & 1133 & 335 & 0.38 & 0.48 & 13 & 1.5 & 2.3 & 5.0 & 1878 & $<$ IDL & 0.46 & 51 & 153 \\
\hline & fibrous fragment & 12 & $<\mathrm{IDL}$ & 37 & 8.6 & 15077 & 235 & 11 & 2.7 & 20 & 3.2 & 8.4 & 11.5 & 10505 & $<$ IDL & 0.85 & 60 & 858 \\
\hline & fibrous fragment & 14 & $<\mathrm{IDL}$ & 344 & 18 & 24632 & 244 & 133 & 6.2 & 53 & 3.4 & 24 & 11.7 & 3268 & $<$ IDL & 0.87 & 119 & 771 \\
\hline & Average & 18 & & 80 & 7.5 & 7660 & 268 & 25 & 3.0 & 27 & 3.3 & 7.5 & 6.3 & 8137 & & 0.71 & 64 & 431 \\
\hline & $S D$ & 15 & & 129 & 5.6 & 9926 & 46 & 53 & 2.7 & 18 & 1.6 & 8.6 & 4.2 & 9718 & & 0.39 & 39 & 365 \\
\hline & Median & 13 & & 31 & 6 & 2003 & 267 & 3 & 2 & 26 & 3 & 5 & 4 & 4777 & & 1 & 60 & 396 \\
\hline & Maximum & 42 & & 344 & 18 & 24632 & 335 & 133 & 6.5 & 53 & 5.3 & 24 & 11.7 & 26558 & & 1.26 & 119 & 858 \\
\hline & Minimum & 0.38 & & 17 & 3.2 & 1112 & 211 & 0.13 & 0.33 & 3.8 & 1.5 & 0.40 & 2.1 & 330 & & 0.11 & 3.6 & 37 \\
\hline
\end{tabular}

* Instrument detection limits for spot size of $55 \mu \mathrm{m}$

molybdenite that originated in connection with opening of inter-lamellar space in molybdenite (Fig. 2b) and also during later stages of molybdenite plastic deformation (Fig. 2c). There is also evidence that tungstenite and other transitional disulfidic $\mathrm{W}-\mathrm{Mo}$ and $\mathrm{Mo}-\mathrm{W}$ phases formed after the molybdenite fragmentation (Fig. 2d). Deformation period started after the formation of molybdenite and lasted to the origin of pyrite that is already undeformed and unfractured (Fig. 2e).

The sequence in sulfidic mineral assemblage (from oldest to youngest) at Vítkov was thus as follows:

arsenopyrite $\rightarrow$ molybdenite $\rightarrow$ tungstenite $\rightarrow$ $\mathrm{W}-\mathrm{Mo} / \mathrm{Mo}-\mathrm{W}$ disulfides $\rightarrow$ pyrite

\subsection{LA-ICP-MS study of molybdenite}

The LA-ICP-MS analyses in molybdenite from greisentype tungsten mineralization at Vítkov show variable metal concentrations (Tab. 1). It should be noted that all $\mathrm{Ni}$ and Re values were below detection limit while anomalous concentrations of W (up to $26558 \mathrm{ppm}$ ), As (up to $24632 \mathrm{ppm}$ ), Bi (up to $858 \mathrm{ppm}$ ), Se (up to 335 $\mathrm{ppm}$ ), $\mathrm{Cu}$ (up to $344 \mathrm{ppm}$ ), $\mathrm{Zr}$ (up to133 ppm), $\mathrm{Ag}$ (up to $53 \mathrm{ppm}$ ), $\mathrm{Sb}$ (up to $24 \mathrm{ppm}$ ), Te (up to $11.7 \mathrm{ppm}$ ), $\mathrm{Nb}$ (up to $6.5 \mathrm{ppm}$ ), Sn (up to $5.3 \mathrm{ppm}$ ) and Au (up to 1.26 $\mathrm{ppm}$ ) were found in a molybdenite grain.

\subsection{Electron-microprobe study of major sulfides}

Results of electron-microprobe study of relatively homogeneous (inclusions-free parts) molybdenite and tungstenite grains are summarized in Tab. 2 and of arsenopyrite in Tab. 3. The detailed study of chemical composition across the molybdenite grain rimmed by tungstenite (Tab. 2) showed relatively homogeneous Mo (59.60-60.66 wt. \%),
S (39.83-40.37 wt. \%) and $\mathrm{W}(0.45-0.59$ wt. \%) values. Rhenium concentrations were below detection limit which varied between 406 and $511 \mathrm{ppm}$ for individual measurements. Tungstenite contains $65.22-69.87$ wt. \% W, 27.07-27.41 wt. \% S and between 3.34 and 5.87 wt. \% of Mo with a strong negative correlation between Mo and $\mathrm{W}(\mathrm{R}=-0.997$, Fig. 3). Locally, a transition from Mo-W and $\mathrm{W}-\mathrm{Mo}$ disulfides to tungstenite, which is often in a sharp contact with molybdenite, can be seen (Fig. 4 and $5 \mathrm{a}-\mathrm{c}$ ).

The EMPA of arsenopyrite which is paragenetically the oldest sulfide revealed relatively homogeneous concentrations of As (45.8-48.2 wt. \%), Fe (32.9-34.8 wt. \%), S (18.2-20.1 wt. \%) and variable Co values (0.023-1.3 wt. \%), locally with traces of Ni (Tab. 3).

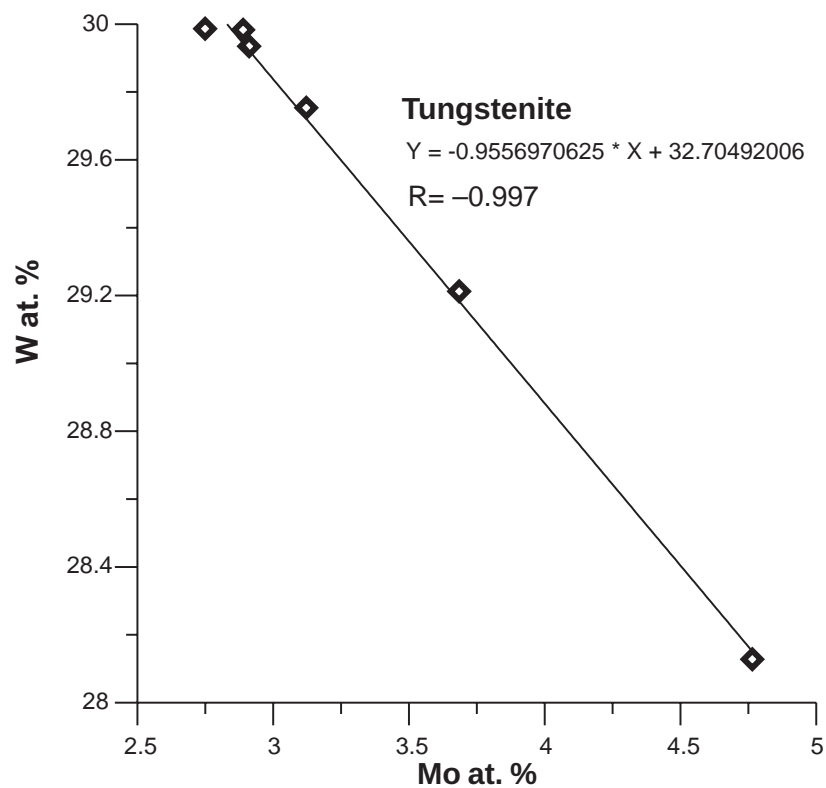

Fig. 3 Mo vs. W plot in tungstenite. Note a significant negative correlation indicating a substitution of $\mathrm{Mo}^{4+}$ for $\mathrm{W}^{4+}$. 
Tab. 2 Chemical composition of molybdenite and tungstenite (EMPA)

\begin{tabular}{|c|c|c|c|c|c|c|c|c|}
\hline \multirow[t]{2}{*}{ Mineral } & \multicolumn{3}{|c|}{ wt. $\%$} & \multicolumn{5}{|c|}{ at. $\%$} \\
\hline & $\mathrm{S}$ & Mo & W & Total & $\mathrm{S}$ & Mo & W & Total \\
\hline \multirow[t]{19}{*}{ molybdenite } & 40.26 & 60.27 & 0.56 & 101.10 & 66.55 & 33.29 & 0.16 & 100 \\
\hline & 40.12 & 60.49 & 0.51 & 101.12 & 66.40 & 33.45 & 0.15 & 100 \\
\hline & 40.06 & 60.45 & 0.49 & 100.99 & 66.38 & 33.48 & 0.14 & 100 \\
\hline & 40.29 & 60.66 & 0.48 & 101.42 & 66.44 & 33.43 & 0.14 & 100 \\
\hline & 40.23 & 60.00 & 0.46 & 100.68 & 66.65 & 33.22 & 0.13 & 100 \\
\hline & 40.30 & 60.30 & 0.45 & 101.05 & 66.58 & 33.29 & 0.13 & 100 \\
\hline & 40.28 & 60.11 & 0.55 & 100.94 & 66.62 & 33.22 & 0.16 & 100 \\
\hline & 40.04 & 60.02 & 0.51 & 100.58 & 66.53 & 33.32 & 0.15 & 100 \\
\hline & 40.31 & 60.09 & 0.57 & 100.96 & 66.64 & 33.20 & 0.16 & 100 \\
\hline & 39.93 & 59.91 & 0.55 & 100.39 & 66.50 & 33.34 & 0.16 & 100 \\
\hline & 40.37 & 59.90 & 0.54 & 100.81 & 66.75 & 33.10 & 0.16 & 100 \\
\hline & 40.13 & 59.99 & 0.53 & 100.65 & 66.59 & 33.26 & 0.15 & 100 \\
\hline & 40.10 & 59.91 & 0.52 & 100.53 & 66.60 & 33.25 & 0.15 & 100 \\
\hline & 39.93 & 59.64 & 0.53 & 100.10 & 66.61 & 33.24 & 0.15 & 100 \\
\hline & 39.83 & 59.62 & 0.59 & 100.04 & 66.54 & 33.28 & 0.17 & 100 \\
\hline & 40.26 & 59.89 & 0.59 & 100.74 & 66.68 & 33.15 & 0.17 & 100 \\
\hline & 40.02 & 59.80 & 0.49 & 100.31 & 66.60 & 33.25 & 0.14 & 100 \\
\hline & 40.04 & 60.28 & 0.58 & 100.90 & 66.42 & 33.42 & 0.17 & 100 \\
\hline & 40.18 & 59.60 & 0.59 & 100.36 & 66.75 & 33.09 & 0.17 & 100 \\
\hline Minimum & 39.83 & 59.60 & 0.45 & & 66.38 & 33.09 & 0.13 & \\
\hline Мaximum & 40.37 & 60.66 & 0.59 & & 66.75 & 33.48 & 0.17 & \\
\hline Average & 40.14 & 60.05 & 0.53 & & 66.57 & 33.28 & 0.15 & \\
\hline \multirow[t]{6}{*}{ tungstenite } & 27.14 & 5.77 & 65.22 & 98.12 & 67.11 & 4.76 & 28.13 & 100 \\
\hline & 27.07 & 3.49 & 69.31 & 99.86 & 67.13 & 2.89 & 29.98 & 100 \\
\hline & 27.20 & 3.53 & 69.53 & 100.26 & 67.15 & 2.91 & 29.93 & 100 \\
\hline & 27.23 & 4.47 & 67.97 & 99.67 & 67.10 & 3.68 & 29.21 & 100 \\
\hline & 27.41 & 3.81 & 69.65 & 100.87 & 67.12 & 3.12 & 29.75 & 100 \\
\hline & 27.34 & 3.34 & 69.87 & 100.55 & 67.26 & 2.75 & 29.99 & 100 \\
\hline Minimum & 27.07 & 3.34 & 65.22 & & 67.10 & 2.75 & 28.13 & \\
\hline Maximum & 27.41 & 5.77 & 69.87 & & 67.26 & 4.76 & 29.99 & \\
\hline Average & 27.23 & 4.07 & 68.59 & & 67.15 & 3.35 & 29.50 & \\
\hline
\end{tabular}

\section{Discussion}

\subsection{Tungsten-bearing greisens in the Bohemian Massif}

Greisens associated with late Variscan granites (Tischendorf 1989; Štemprok et al. 1997) are a common host of tin and tungsten ores in the $\mathrm{Sn}-\mathrm{W}$ metallogenic province of Central Europe (Štemprok and Seltmann 1994). They are metasomatic rocks mostly formed from a granite precursor, and consist of quartz, mica (Li-Fe mica or muscovite; forming either Li-rich or Li-poor greisens), and/or topaz. The greisens are spatially related to the tin and tungsten mineralization of the Younger Intrusive Complex (YIC) granites of the Krušné hory/Erzgebirge granite Batholith. Among the ore minerals, the greisens contain cassiterite, wolframite, and/or scheelite in variable combinations and proportions, in addition to a small amount of sulfides (Štemprok et al. 2005). No tungstenite and/or transitional $\mathrm{W}-\mathrm{Mo} / \mathrm{Mo}-\mathrm{W}$ disulfides were reported from these occurrences. The presence of rare micro-inclusions (up to $3 \mu \mathrm{m}$ across) of tungstenite in cassiterite from granite at Přibyslavice was described by Breiter et al. (2006).

The W-bearing greisens and quartz veins are found within a large outer tungsten metallogenic zone that encircles the granites of the Western Krušné hory/Erzgebirge Batholith (Štemprok and Seltmann 1994), and are characteristic of the western part of the Krušné hory/Erzgebirge ore province. For example, a W-bearing greisen was found at Boží Dar in the eastern contact zone of the Nejdek-Eibenstock Massif by Absolonová (1978) and at Vykmanov by Štemprok (1984). At Boží Dar, the deposits occur

Tab. 3 Chemical composition of arsenopyrite (EMPA)

\begin{tabular}{|c|c|c|c|c|c|c|c|c|c|c|c|c|}
\hline \multirow[t]{2}{*}{ Mineral } & \multicolumn{5}{|c|}{ wt. \% } & \multicolumn{7}{|c|}{ at. $\%$} \\
\hline & $\mathrm{Fe}$ & Co & $\mathrm{Ni}$ & As & $\mathrm{S}$ & Total & $\mathrm{Fe}$ & Co & $\mathrm{Ni}$ & As & $\mathrm{S}$ & Total \\
\hline \multirow[t]{6}{*}{ arsenopyrite } & 33.03 & 1.32 & 0.12 & 47.80 & 18.27 & 100.55 & 32.50 & 1.23 & 0.11 & 35.05 & 31.30 & 100 \\
\hline & 32.93 & 1.12 & 0.15 & 48.21 & 18.19 & 100.60 & 32.38 & 1.04 & 0.14 & 35.33 & 31.15 & 100 \\
\hline & 34.43 & 0.03 & 0.05 & 46.98 & 19.14 & 100.62 & 33.48 & 0.02 & 0.04 & 34.05 & 32.42 & 100 \\
\hline & 34.80 & 0.05 & 0.01 & 45.83 & 20.11 & 100.81 & 33.48 & 0.05 & 0.01 & 32.87 & 33.71 & 100 \\
\hline & 34.53 & 0.04 & 0.03 & 46.45 & 19.46 & 100.51 & 33.51 & 0.04 & 0.03 & 33.60 & 32.89 & 100 \\
\hline & 33.12 & 1.21 & 0.10 & 47.80 & 18.48 & 100.71 & 32.45 & 1.12 & 0.10 & 34.91 & 31.53 & 100 \\
\hline Minimum & 32.93 & 0.03 & 0.01 & 45.83 & 18.19 & & 32.38 & 0.02 & 0.01 & 32.87 & 31.15 & \\
\hline мaximum & 34.80 & 1.32 & 0.15 & 48.21 & 20.11 & & 33.51 & 1.23 & 0.14 & 35.33 & 33.71 & \\
\hline Average & 33.82 & 0.64 & 0.08 & 47.14 & 18.99 & & 32.96 & 0.60 & 0.07 & 34.25 & 32.23 & \\
\hline
\end{tabular}




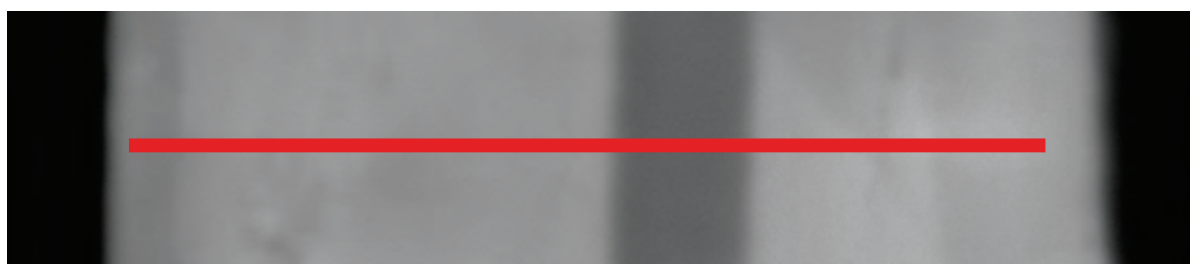

Fig. 4 Energy-dispersive X-ray spectroscopy linescan of the distribution of Mo, W and S across the molybdenite-tungstenite boundary. Note a sharp contact between molybdenite and tungstenite which does not indicate any cation exchange.

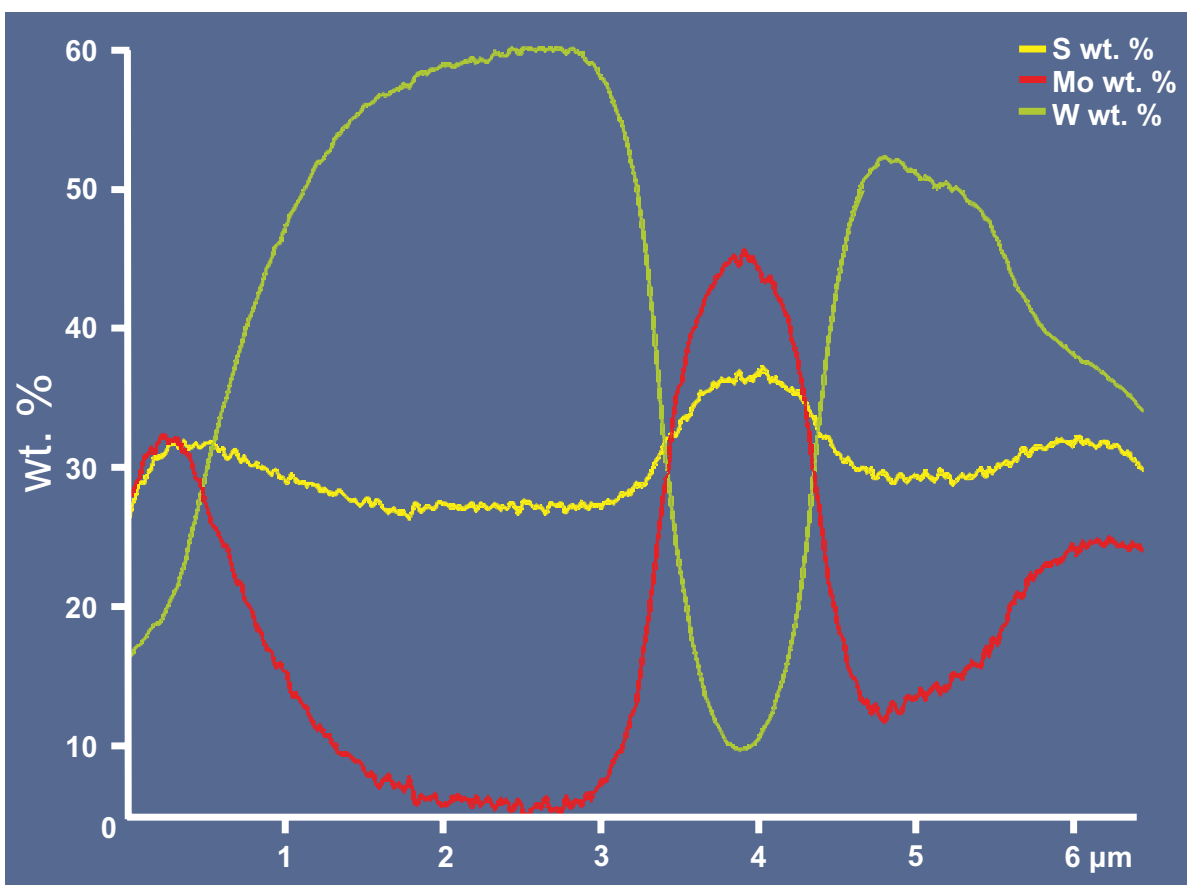

in the form of quartz-mica and quartz-topaz greisens with wolframite (ferberite), molybdenite, and native bismuth (Absolonová 1978). The W-bearing topaz greisen at Vykmanov contains ferberite rarely with accessory Fe-columbite or is accompanied by scheelite and rare native bismuth (Štemprok et al. 2005). These authors suggested that the greisen formed from $\mathrm{CO}_{2}-$ poor hydrothermal solutions at about $400{ }^{\circ} \mathrm{C}$. The solutions evolved from highly saline brines; these mostly magmatic fluids were taken responsible for the $\mathrm{W}-\mathrm{Bi}$ specialization of the greisen. Fluid inclusion study in quartz and topaz from W-bearing greisen at Vítkov (Sidorinová and Dobeš in print) identified primary water-rich inclusions that homogenized at $312-358^{\circ} \mathrm{C}$ (minimum $\mathrm{T}$ of the origin of minerals), however indicating lower salinity fluids $(4.0-7.6$ wt. $\% \mathrm{NaCl}$ equivalent). This also differs from other types of tungsten mineralizations bound to a crystalline envelope of the Krkonoše-Jizera Pluton that showed the presence of two-phase $\left(\mathrm{H}_{2} \mathrm{O}-\mathrm{CO}_{2}\right)$ inclusions with similar homogenization temperatures and salinities (Vondrovic et al. 2011) or different salinities (Karwowski 1973) when compared to Vítkov.

\subsection{Chemistry of molybdenite at Vítkov}

It has been suggested that Re is homogeneously distributed in the molybdenite lattice (e.g. Frondel and Wickman 1970). Molybdenite has been shown to be the major host for Re in many hydrothermal ore deposits (McCandless et al. 1993). Rhenium concentrations vary widely in different types of mineral associations with the highest concentrations in porphyry-type $\mathrm{Cu}-\mathrm{Mo}(\mathrm{Au})$ deposits (Berzina et al. 2005 and others). Molybdenite from topaz greisen at Vítkov yields very low Re but high $\mathrm{W}$ concentrations. These low Re contents are consistent with Stein (2006), who reported very low concentrations of Re (sub-parts of ppm) in molybdenite from greisentype associations and suggested that they were indicative of crustal sources of Re.

Drábek et al. (1989 and 1993) first determined Re, $\mathrm{W}$, Se and Te contents in molybdenite separated from different types of Mo-mineralization of the Bohemian Massif. They concluded that molybdenite from greisentype deposits contains $1-11 \mathrm{ppm}$ Re (avg. $3 \mathrm{ppm}, \mathrm{n}=$ 16), 43-9300 ppm W (avg. $450 \mathrm{ppm}, \mathrm{n}=21$ ), 15-200 ppm Se (avg. $120 \mathrm{ppm}, \mathrm{n}=19)$ and $2-14.4 \mathrm{ppm} \mathrm{Te}$ 

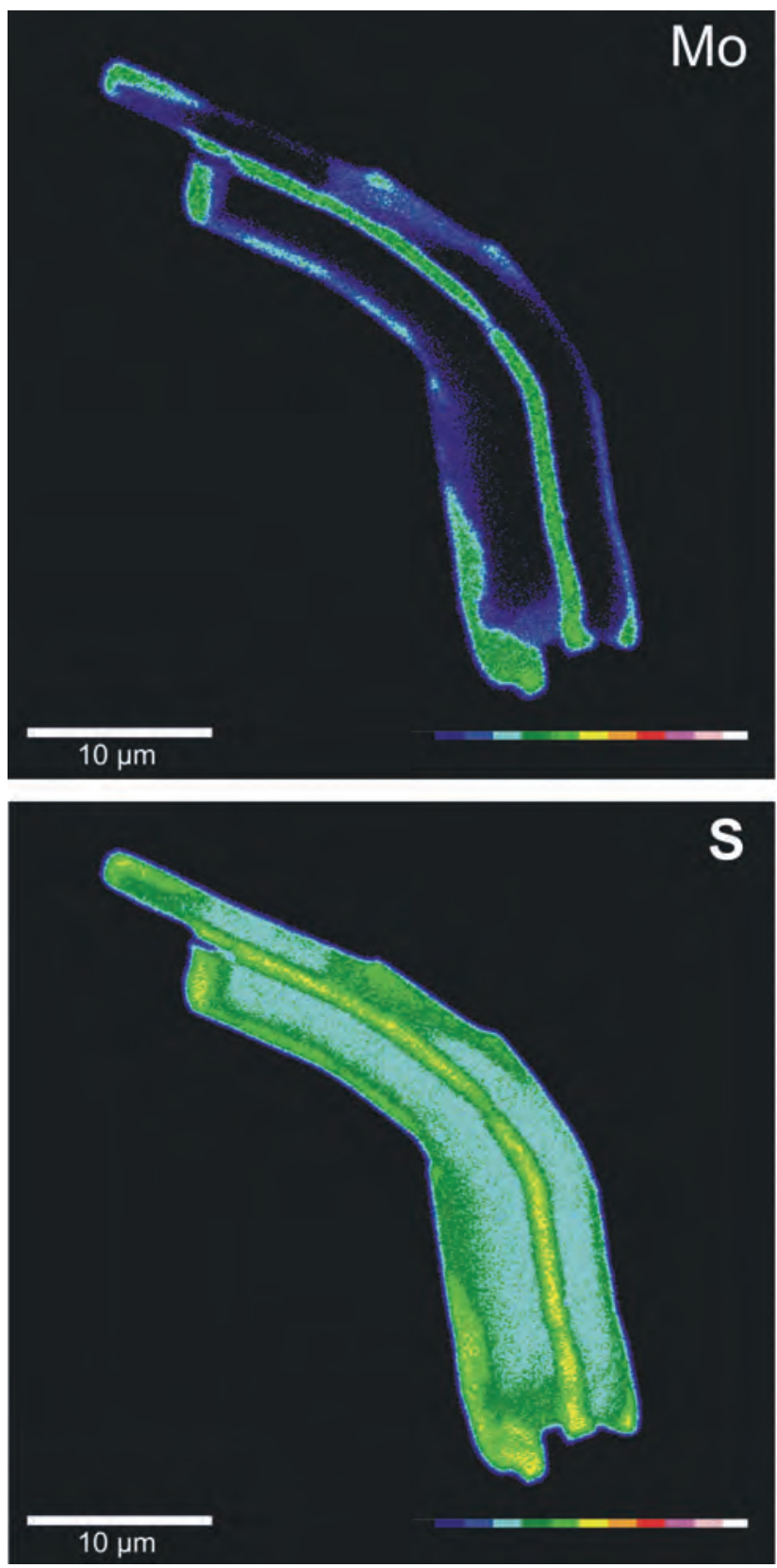

(avg. 7 ppm $\mathrm{n}=9$ ). Except of Re and Te, such average values are much lower than those of molybdenite from Vítkov $(\mathrm{W}=5300$ ppm; Tab. 1 or $\mathrm{W}=8137 \mathrm{ppm}$ and $\mathrm{Se}=268$ ppm; Tab. 3).

Pašava et al. (2016) studied in situ variation in chemical composition of molybdenite from different types of mineral associations in the Bohemian Massif. The highest average contents of $\mathrm{Cu}(58 \mathrm{ppm}), \mathrm{Zn}$ (45 ppm), As $(40 \mathrm{ppm})$ and Co $(3 \mathrm{ppm})$ were detected in greisenrelated molybdenite while the highest average values of Bi (1150 ppm), Ag (434 ppm), Te (111 ppm), Sb (38 $\mathrm{ppm})$ and $\mathrm{Au}(24 \mathrm{ppm})$ were found in molybdenite from gold deposits.

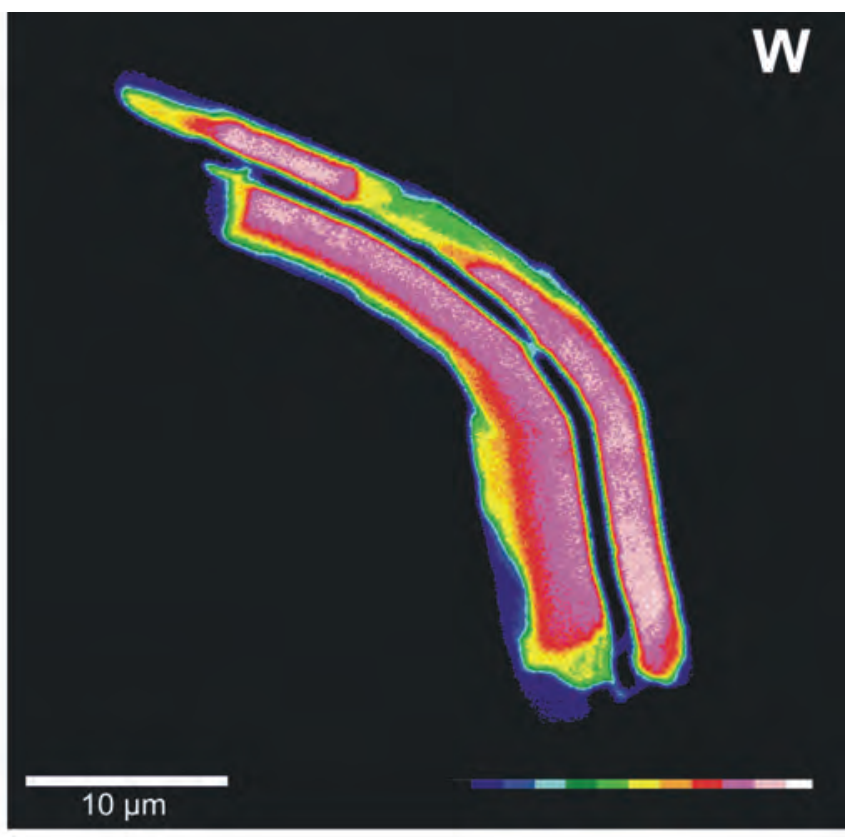

Fig. 5 Distribution map of Mo, W and $\mathrm{S}$ in a sulfide fragment composed of molybdenite, tungstenite and transitional W-Mo and Mo-W disulfidic phases (cf. Fig. 2d).

Similarly to Re, Frondel and Wickman (1970) suggested that tungsten is also often homogeneously incorporated in the molybdenite lattice. The content of $\mathrm{W}$ in molybdenite reflects both the abundance of this element in magmatic system and its chemical bond, which depends on the $\mathrm{S}_{2} / \mathrm{O}_{2}$ activity ratio. The latter strongly controls whether tungsten joins an oxidic or sulfidic bond (e.g. Štemprok 1971; Drábek 1982 and others). We document that $\mathrm{W}$ concentrations of up to $0.5 \mathrm{wt}$. \% found in our low-Re inclusion-free molybdenite are very likely related to its presence in the lattice. Higher $\mathrm{W}$ concentrations are, however, associated with detected nano- to micron-scale inter-lamellar fillings and/or intergrowths of tungstenite 


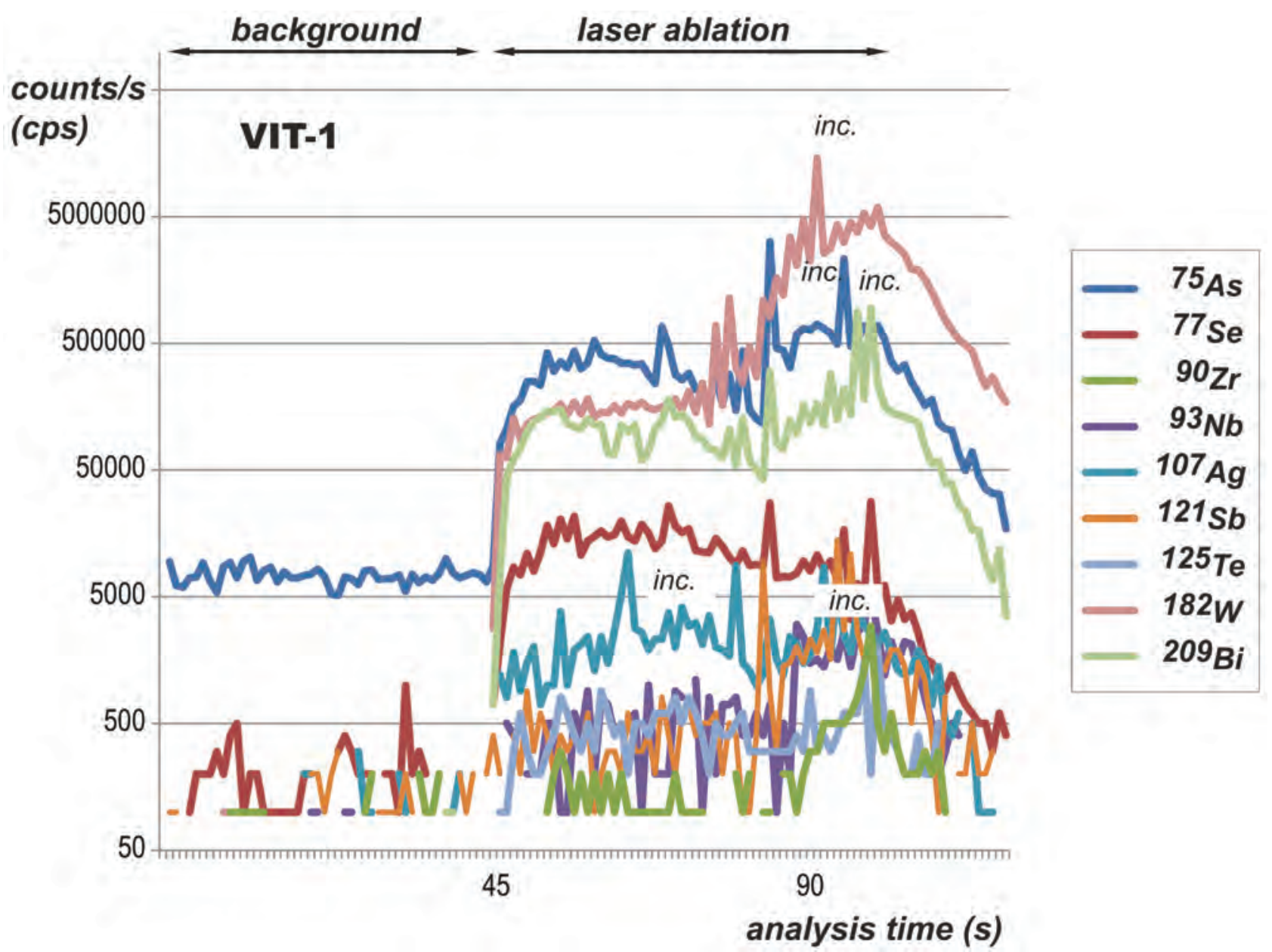

Fig. 6 Representative time-resolved LA-ICP-MS depth profile for molybdenite from Vítkov to show noisiness of signals for Ag, As, Bi, Nb, Sb, $\mathrm{Zr}$ and $\mathrm{W}$ indicating presence of impurities and contrasting with flat signals for lattice-bound elements ( $\mathrm{Se}$ and $\mathrm{Te}$ ).

with molybdenite and also related to transitional $\mathrm{W}-\mathrm{Mo} /$ Mo-W disulfides.

The presence of As, $\mathrm{Ag}, \mathrm{Bi}, \mathrm{Nb}, \mathrm{Sb}, \mathrm{Zr}$ and $\mathrm{W}$ impurities and most likely isomorphic Se and Te admixtures are indicated by the differing response from trace elements in the time resolved LA-ICP-MS depth profiles from molybdenite at Vítkov (Fig. 6).

\subsection{Tungstenite-molybdenite relationship}

Tungstenite $\left(\mathrm{WS}_{2}\right)$ is isotypic with molybdenite $\left(\mathrm{MoS}_{2}\right)$ and the ionic radius of $\mathrm{Mo}^{4+}(0.65 \AA)$ is very close to that of $\mathrm{W}^{4+}(0.66 \AA$; Shannon 1976). Both these sulfides form hexagonal $(2 H)$ and trigonal $(3 R)$ polytypes (e.g., Gait and Mandarino 1970). Moh and Udubasa (1976) studied the phase relations within the Mo-W-S system at $500-1000^{\circ} \mathrm{C}$ and reported a complete solid solution between the hexagonal $\mathrm{MoS}_{2}$ and $\mathrm{WS}_{2}$. Similar complete molybdenite-tungstenite solid solution was also described in a low-temperature mineral assemblage from the Felbertal scheelite deposit (Hohe Tauern, Austria) by Höll and Weber-Diefenbach (1973). Barkov et al. (2000a) reported the molybdenite zoned with respect to tungsten from fenitized megaxenolith in the Khibina alkaline Complex, Kola Peninsula, Russia. Tungsten was strongly enriched in the central zone of molybdenite (up to $5.85 \mathrm{wt}$. \%). We have not confirmed any zonality in the $\mathrm{W}$ distribution in molybdenite at Vítkov, though. Štemprok (1971) examined phase relations within the $\mathrm{Fe}-\mathrm{W}-\mathrm{S}$ system and discussed the sulfur fugacity therein. His investigation confirmed the stability of the FeS-W tie line and confirmed the position of $\mathrm{WS}_{2} / \mathrm{W}$ curve above that of $\mathrm{FeS} / \mathrm{Fe}$; $\mathrm{WS}_{2}-\mathrm{Fe}$ join was not stable. Conversely, according to Kullerud (1966) and Grover et al. (1975), $\mathrm{MoS}_{2}$ is stable with metallic Fe. These differences in behavior indicate different affinities of $\mathrm{W}$ and Mo to sulfur (Barkov et al. 2000a, b). At the low $f\left(\mathrm{O}_{2}\right)$ fugacity, elements such as $\mathrm{W}, \mathrm{Ti}$ or $\mathrm{Nb}$ with lithophile behavior can become chalcophile (Barkov et al. 1997; 2000a, b). Noticeable lack of $\mathrm{W}^{4+}$ in molybdenite results from its formation at highly oxidizing conditions (Barkov et al. 2000a). 


\section{$577^{\circ} \mathrm{C}, 100 \mathrm{MPa}$}

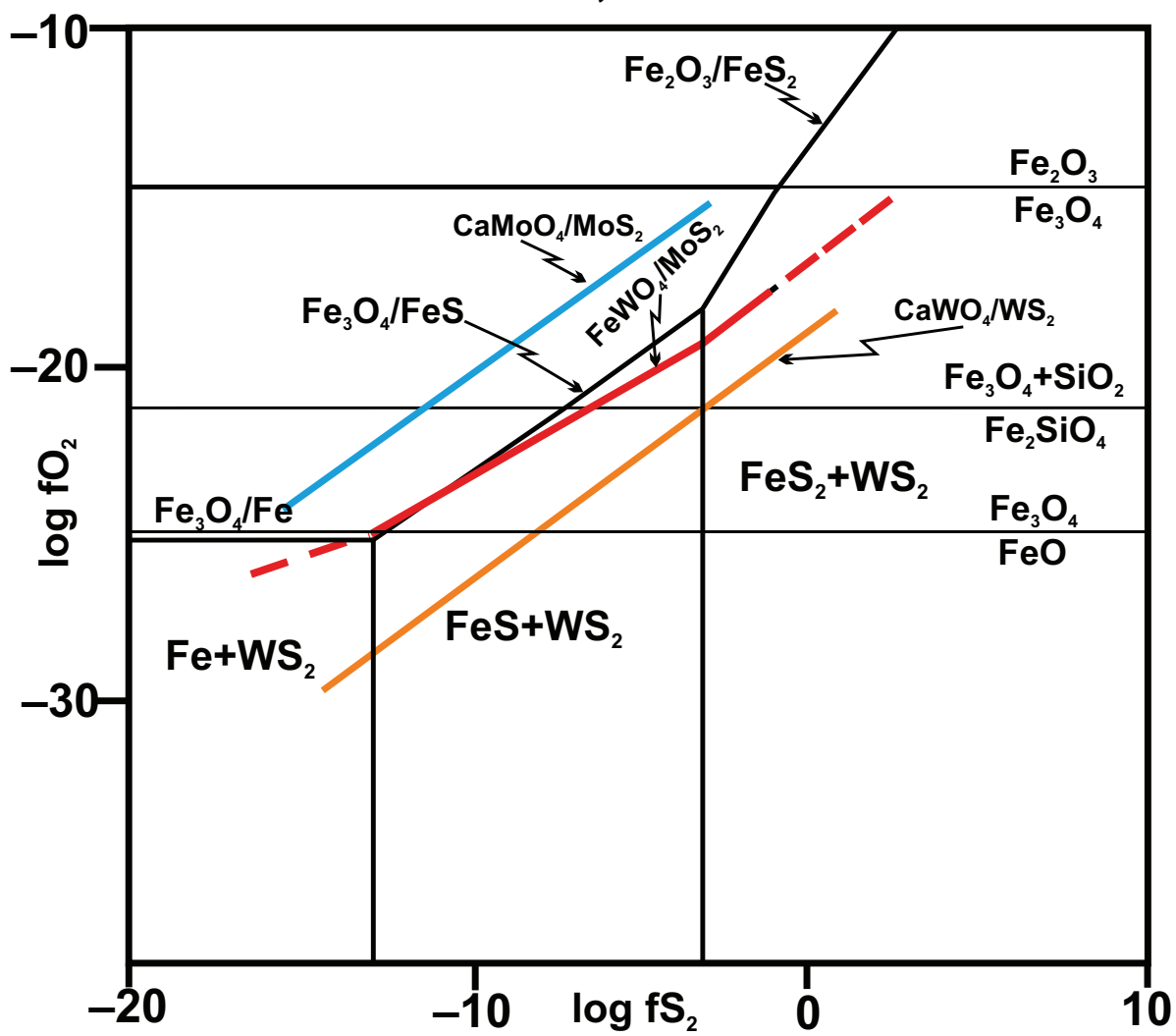

Fig. 7 The $\log \mathrm{fS}_{2}$ vs. $\log \mathrm{fO}_{2}$ diagram indicating the stability fields of tungstenite, molybdenite, ferberite, scheelite and powellite at $577^{\circ} \mathrm{C}$ and $100 \mathrm{MPa}$ fluid pressure. Adapted from Hsu (1976, 1977). Stability fields of iron sulfides and oxides are shown for comparison.
Hsu (1977) studied the stability of molybdenite, scheelite and powellite and Hsu (1976) the stability of tungstenite and ferberite. His results are summarized in a plot of $\log f\left(\mathrm{~S}_{2}\right)$ vs. $f\left(\mathrm{O}_{2}\right)$ showing the stability fields of tungstenite $\left(\mathrm{WS}_{2}\right)$, ferberite $\left(\mathrm{FeWO}_{4}\right)$, molybdenite $\left(\mathrm{MoS}_{2}\right)$, scheelite $\left(\mathrm{CaWO}_{4}\right)$ and powellite $\left(\mathrm{CaMoO}_{4}\right)$ (Fig. 7). From this diagram follows that tungstenite crystalizes at the low oxygen fugacity while ferberite or scheelite are formed at more oxidizing conditions. Similarly at a higher $f\left(\mathrm{O}_{2}\right)$, powellite originates instead of molybdenite. The formation of powellite, however, requires over five orders of magnitude higher $f\left(\mathrm{O}_{2}\right)$ than needed for scheelite. Molybdenite is not stable in the presence of hematite (Drábek 1982) and tungstenite is not stable in the presence of iron oxides (Štemprok 1971).

\subsection{Implications for the origin of sulfide association at Vítkov}

Sidorinová and Dobeš (in print) reported only water-rich inclusions from quartz and topaz of greisen at Vítkov. Mineral paragenesis and fluid-inclusion data indicate that oxidizing aqueous fluids rich in rare metals precipitated wolframite and scheelite during oxide-dominated conditions while the change of physico-chemical conditions (strong decrease in $\mathrm{fO}_{2} / \mathrm{S}_{2}$ ) resulted in the formation of sulfidic assemblage. After arsenopyrite (that scavenged most of As and Fe available in the system) followed precipitation of molybdenite with up to $0.5 \mathrm{wt}$. \% of W. Later on, after decreasing $f\left(\mathrm{O}_{2}\right)$, conditions shifted into the stability field of $\mathrm{W}^{4+}$ ions (below $\mathrm{WO}_{2}-\mathrm{WO}_{3}$ buffer; Cygan and Chou 1990). This triggered crystallization of tungstenite in the form of "inclusion-like" lamellae in the inter-lamellar space, parallel to the basal faces of the molybdenite crystals. The contacts between older molybdenite and younger tungstenite are sharp without any exchange of cations (Fig. 4).

Probably still younger were changes in $\mathrm{Mo} / \mathrm{W}$ ratio in tungstenite growing at outer margins of the molybdenite aggregates. In this case molybdenite-tungstenite contacts remain sharp, but peripheral zones are poorer in $\mathrm{W}$, reflecting most likely later changes in the activity of $\mathrm{W}^{4+}$ in the mineralizing fluid (Fig. 4 and $5 \mathrm{a}-\mathrm{c}$ ). Zoned tungstenite crystals and sharp tungstenite-molybdenite contacts indicate disequilibrium conditions during their formation.

\section{Conclusions}

The detailed mineralogical investigation of sulfide assemblage from W-bearing topaz greisen at Vítkov followed by LA-ICP-MS and EMP study resulted in the following conclusions: 
1. The origin of sulfide-rich assemblage started with the precipitation of arsenopyrite, followed by the formation of molybdenite, tungstenite, Mo-W and $\mathrm{W}-\mathrm{Mo}$ transitional disulfides and, finally, by pyrite. This is for the first time when molybdenite associated with tungstenite and Mo-W and $\mathrm{W}-\mathrm{Mo}$ disulfidic phases is described from W-bearing topaz greisen in the Bohemian Massif.

2. LA-ICP-MS analyses of molybdenite showed extreme concentrations of W (up to 26558 ppm) accompanied by elevated values of other metals (e.g., As, $\mathrm{Bi}, \mathrm{Se}, \mathrm{Cu}$, $\mathrm{Pb}$ and $\mathrm{Ag}$ ) and very low Re values (below $0.3 \mathrm{ppm}$ ), consistent with the crustal source of metals.

3. Electron-microprobe analyses of inclusion-free molybdenite yielded the average value of $\sim 0.5 \mathrm{wt}$. \% of $\mathrm{W}$ most likely bound into the crystal lattice. Inclusion-free tungstenite contains on average $\sim 4$ wt. $\%$ of Mo that shows a strong negative correlation with $\mathrm{W}$, indicating a substitution of $\mathrm{Mo}^{4+}$ for $\mathrm{W}^{4+}$.

4. Textural features, along with the stability and phase relationships between molybdenite, tungstenite and transitional Mo- and W-dominated disulfides suggest that precipitation of molybdenite took place at relatively high $\mathrm{fO}_{2}$. The subsequent crystallization of tungstenite was triggered by a decrease in $\mathrm{fO}_{2}$ below the $\mathrm{WO}_{2}-\mathrm{WO}_{3}$ buffer. Sharp boundaries between tungstenite and molybdenite and locally zoned tungstenite indicate disequilibrium during their formation.

Acknowledgements. This study is a contribution to the GAČR project S13-15390S. The manuscript has benefited from stimulating reviews by S. Mikulski, R. Skála and also M. Štemprok and V. Janoušek, whose efficient editorial handling is greatly appreciated.

\section{References}

Absolonová E (1978) Discovery of blind tungsten and molybdenum mineralization near Boží Dar in the western part of the Krušné hory Mts. Věst Ústř Úst geol 53: 163-168 (in Czech)

Barkov AY, LaAjoki KVO, Men'shikov YP, Alapieti TT, Sivonem SJ (1997) First terrestrial occurrence of titanium-rich pyrrhotite, marcasite and pyrite in a fenitized xenolith from the Khibina alkaline Complex, Russia. Canad Mineral 35: 875-885

Barkov AY, Martin RF, Poirier G (2000a) Zoned tungstenoan molybdenite from fenitized megaxenolith in the Khibina Alkaline Complex, Kola Peninsula, Russia. Canad Mineral 38: 1377-1385

Barkov AY, Martin RF, Men'shikov YP, Savchenko Ye, Thibault Y, LaAjoki KVO (2000b) Edgarite, $\mathrm{FeNb}_{3} \mathrm{~S}_{6}$, first natural niobium-rich sulfide from the Khibina alkaline Complex, Russian Far North; evidence for chalcophile behavior of $\mathrm{Nb}$ in a fenite. Contrib Mineral Petrol 138: 229-236

Behr HJ, Engel W, Franke W, Giese P, Weber K (1984) The Variscan belt in central Europe: main structures, geodynamic implications, open questions. Tectonophysics 109:15-40

Berzina AN, Sotnikov VL, Economou-Eliopoulos M, Eliopoulos DC (2005) Distribution of rhenium in molybdenite from porphyry $\mathrm{Cu}-\mathrm{Mo}$ and $\mathrm{Mo}-\mathrm{Cu}$ deposits of Russia (Siberia) and Mongolia. Ore Geol Rev 26: 91-113

BLEVIN P, JACKSON S (1998) Potential applications of LAMICP-MS technology in economic geology: a preliminary study of molybdenite and pyrite. Abstract, $14^{\text {th }}$ Australian Geological Convention, Townsville, 6-10 July 1998, Geological Society of Australia, Sydney, pp 1-506

Breiter K, Škoda R, Starý J (2006) Tin, niobium and tantalum mineralization at Přibyslavice near Č́slav. Zpr geol Výzk v Roce 2005, 102-107

Chrt J, Bolduan H, Fedak J, Holzer H, Teuscher EO (1968) Karte der postmagmatischen Mineralization der Böhmischen Masse. Z Angew Geol, Bd 14: 362-376

Ciobanu CL, Cook NJ, Kelson CR, Guerin R, Kalleske N, DANYushevsky L (2013) Trace element heterogeneity in molybdenite fingerprints stages of mineralization. Chem Geol 347: 175-189

Cook NJ, Ciobanu CL, Mao J (2009) Textural controls on gold distribution in As-free pyrite from the Dongping, Huangtuliang and Hougou gold deposits, North China Craton (Hebei Province, China). Chem Geol 264: 101-121

Cook NJ, Ciobanu CL, Meria D, Silcock D, Wade B (2013) Arsenopyrite-pyrite association in an orogenic gold ore: tracing mineralization history from textures and trace elements. Econ Geol 108: 1273-1283

Cygan GL, Chou I-Ming (1990) The assemblage $\mathrm{WO}_{2}+$ $\mathrm{H}_{2} \mathrm{O}$ as a steady-state hydrogen source in moderately reduced hydrothermal experiments. Amer Miner 75: 1399-1405

DrÁBEK M (1982) The system Fe-Mo-S-O and its geologic applications. Econ Geol 77: 1053-1056

Drábek M, KvaČek M, KorečKová J, Weiss D (1989) Tellurium contents in molybdenites from the Bohemian Massif. Věst Ústř Úst geol 64: 43-46 (in Czech)

DRÁBEK M, DrÁBKovÁ E, KVAČEK M (1993) Distribution of rhenium, tungsten and selenium in molybdenites of the Bohemian Massif. Věst Čes geol úst 68: 11-17

FARYAD SW, KACHLí́ V (2013) New evidence of blueschist facies rocks and their geotectonic implication for Variscan suture(s) in the Bohemian Massif. J Metamorph Geol 31: 63-82

Franke W, Źelażniewicz A, Porćebski SJ, Wajsprych B (1993) Saxothuringian Zone in Germany and Poland: differences and common features. Geol Rundsch 82: 583-599 
Frondel JW, Wickman FE (1970) Molybdenite polytypes in theory and occurrence. II. Some naturally-occurring polytypes of molybdenite. Amer Miner 55: 1857-1875

Gait RI, Mandarino JA (1970) Polytypes of tungstenite. Canad Mineral 10: 729-731

Grover B, Kullerud GH, Moн GH (1975) Phasengleichgewichtsbeziehungen im ternären System Fe-Mo-S in Relation zu natürlichen Mineralien und Erzlagerstätten. Neu Jb Mineral, Abh 124: 246-272

Höll R, Weber-Diefenbach K (1973) Tungstenit und Molybdänit-Mischphasen in der Scheelitlagerstätte Felbertal (Hohe Tauern, Österreich). Neu Jb Mineral, Mh 27-34

Hsu LC (1976) The stability relations of the wolframite series. Amer Miner 61: 944-955

Hsu LC (1977) Effect of oxygen and sulfur fugacities on the scheelite-tungstenite and powellite-molybdenite stability relations. Econ Geol 72: 664-670

KaChlík V, РАтос̌Ka F (1998) Cambrian/Ordovician intracontinental rifting and Devonian closure of the rifting generated basins in the Bohemian Massif realms. Acta Univ Carol, Geol 42: 433-441

Karwowski $Ł$ (1973) Greisens in the Mlądz-KamieńPobiedna region in the Jizera Mts. Acta Geol Pol 23: 325-340 (in Polish)

KARWOWsKi Ł (1977) Geochemical conditions of greisenization in the Jizera Mts. (Dolny Śląsk). Arch Mineral 33: 85-146

Klomínský J, Fediuk F, Schovánek P, Jarchovský T, TÁBorSKÝ Z (2003) Topaz quartzolite (greisen) near Chrastava in Northern Bohemia - metallogenic indicator of the WSn mineralization. Zpr geol Výzk v Roce 2003, 112-114 (in Czech with English abstract)

Kossmat F (1927) Gliederung des varistischen Gebirgsbaues. Abh Sächs Geol Landesamt 1: 1-39

Košler J, Simonetti A, Sylvester PJ, Cox RA, Tubrett MN, Wilton DHC (2003) Laser-Ablation ICP-MS measurements of Re/Os in molybdenite and implications for Re-Os geochronology. Canad Mineral 41: 307-320

Kozlowska M (1956) Greisens from Kamień near Mirsk in the Sudetes. Arch Mineral 19: 59-74 (in Polish)

Kullerud GH (1966) The Fe-Mo-S system. Carnegie Institution of Washington, Year Book 65: 337-342

KvaČEK M, TRDLIČKa Z (1970) Die Rhenium und Selengehalte in einigen Molybdäniten der Böhmischen Masse. Acta Univ Carol, Geol 2: 105-111

KvaČEK M, Rezek K, DrÁBek M (1983) Mineralogical and geochemical study of Mo-ores in the Bohemian Massif. Unpublished Internal Report, Institute of Raw Materials (ÚNS), Kutná Hora, pp 1-143 (in Czech)

Large RR, Danyushevsky L, Hollit C, Maslennikov V, Mefrre S, Gilbert S, Bull S, Scott R, Emsbo P, Thomas H, Singh B, Foster J (2009) Gold and trace element zonation in pyrite using a laser imaging technique: implications for the timing of gold in orogenic and Carlin-style sediment-hosted deposits. Econ Geol 104: 635-668

Large RR, Halpin JA, Danyushevsky LV, Maslennikov VV, Bull SW, Long JA, Gregory DD, Lounejeva E, Lyons TW, SAck PJ, McGoldrick PJ, CAlver CR (2014) Trace element content of sedimentary pyrite as a new proxy for deep-time ocean-atmosphere evolution. Earth Planet Sci Lett 389: 209-220

Lin Ye, Cook NJ, Ciobanu CL, Liu YP, Zhang Q, Liu TG, Gao W, Yang YL, Danyushevskiy L (2011) Trace and minor elements in sphalerite from base metal deposits in South China: a LA-ICPMS study. Ore Geol Rev 39: 188-217

Maluski H, PAtočKa F (1997) Geochemistry and ${ }^{40} \mathrm{Ar} /{ }^{39} \mathrm{Ar}$ geochronology of the mafic metavolcanic rocks from the Rýchory Mountains Complex (West Sudetes, Bohemian Massif): palaeotectonic significance. Geol Mag 134: 703-716

McCandless TE, Ruiz J, Campbell AR (1993) Rhenium behaviour in molybdenite in hypogene and near-surface environments: implications for Re-Os geochronology. Geochim Cosmochim Acta 57: 889-905

MikULSki SZ, Stein HJ (2011) Re-Os ages for molybdenites from the Variscan Karkonosze Massif and its eastern metamorphic cover (SW Poland). In: BARRA F, REICH M, Campos E, Tornos F (eds) Let's Talk Ore Deposits. Proceedings of the $11^{\text {th }}$ Biennial SGA Meeting. Ediciones Universidad Catolica del Norte, Antofagasta, pp 130-133

Mochnacka K, Oberc-Dziedzic T, Mayer W, Pieczka A (2015) Ore mineralization related to geological evolution of the Karkonosze-Izera Massif (the Sudetes, Poland) towards a model. Ore Geol Rev 64: 215-238

Moн GH, Udubasa G (1976) Molybdänit-TungstenitMischkristalle und Phasenrelation im System Mo-W-S. Chem Erde 35: 327-335

Norman M, Bennett V, Blevin P, McCulloch M (2004) New Re-Os ages of molybdenite from granite-related deposits of eastern Australia using an improved multicollector ICP-MS technique. In: BIERLEIN FP, Hough MA (eds) Tectonics to Mineral Discovery - Deconstructing the Lachlan Orogen. MORE-SGEG Conference, July 6-8, 2004, Proceedings Volume and Field guide. Geological Society of Australia, Orange NSW, pp 129-132

Pašava J, Frimmel H, Vymazalová A, Dobeš P, Jukov AV, Koneev R (2013) A two stage evolution model for the Amantaytau orogenic-type gold deposit in Uzbekistan. Miner Depos 48: 825-840

Pašava J, Veselovský F, Pour O, Drábek M, Halodová P, Svojtka M, Ackerman L, Ďurišová J, Žák K, HaluzovÁ E (2015) Variation in trace element composition in molybdenite: results of LA-ICP-MS study from different types of mineralization. In: ANDrÉ-MAYER AS, Cathelineau M, Muchez P, Pirard E, Sindern S (eds) Mineral Resources in Sustainable World. Proceedings 
of the $13^{\text {th }}$ Biennial SGA Meeting. Lorraine University, Nancy, pp 615-618

Pašava J, SvojtKa M, Veselovský F, Ďurišová J, Ackerman L, Pour O, Drábek M, Halodová P, Haluzová E (2016) Laser ablation ICP-MS study of trace element chemistry in molybdenite coupled with scanning electron microscopy (SEM) - an important tool for identification of different types of mineralization. Ore Geol Rev 72: 874-895

Selby D, Creaser RA (2004) Macroscale NTIMS and microscale LA-MC-ICP-MS Re-Os isotopic analysis of molybdenite: testing restrictions for reliable Re-Os age determinations, and implications for the decoupling of Re and Os within molybdenite. Geochim Cosmochim Acta 68: 3897-3908

SHANNON RD (1976) Revised effective ionic radii and systematic studies of interatomic distances in halides and chalcogenides. Acta Crystallogr 32A: 751-767

Sidorinová T, Dobeš P (in print) Tungsten mineralization in the topaz greisen of the Krkonoše-Jizera Crystalline Complex at the locality Vítkov. Geoscience Research Reports of the Czech Geological Survey for 2014, doi: 10.3140/zprávy.geol.2014.37 (in Czech)

Stein HJ (2006) Low-rhenium molybdenite by metamorphism in northern Sweden: recognition, genesis, and global implications. Lithos 87: 300-327

Stein HJ, Markey RJ, Morgan JW, Hannah JL, Schersten A (2001) The remarkable Re-Os chronometer in molybdenite: how and why it works. Terra Nova 13: 479-486

Stein HJ, Schersten A, Hannah JL, Markey RJ (2003) Subgrain decoupling of Re and ${ }^{187} \mathrm{Os}$ and assessment of laser ablation ICP-MS spot dating in molybdenite. Geochim Cosmochim Acta 67: 3673-3686

Sung YH, Brugger J, Ciobanu CL, Pring A, Skinner W, Danyushevsky L, Nugus M (2009) Invisible gold in arsenian pyrite and arsenopyrite from a multistage Archean gold deposit: Sunrise Dam, Eastern Goldfields Province, Western Australia. Miner Depos 44: 765-791

ŠтемPROK M (1971) The iron-tungsten-sulphur system and its geological application. Miner Depos 6: 302-312

ŠTEMPROK M (1984) Evaluation of the tungsten and tin mineralisation of the Vykmanov granite massif near Ostrov n. Ohří. Geol Průzk 26: 65-69 (in Czech)

ŠTemprok M, Seltmann R (1994) The metallogeny of the Erzgebirge (Krušné hory). In: Seltmann R, KämPF H,
MöLler P (eds) Metallogeny of Collisional Orogens. Czech Geological Survey, Prague, pp 61-69

ŠTemprok M, Chlupáčová M, Pivec E, Novák JK, LANG M (1997) Petrochemical and petrophysical changes caused by greisenization in the younger granites of the Krušné hory batholith (Czech Republic). In: PAPPUNeN H (ed) Mineral Deposits: Research and Exploration. Where Do They Meet? Proceedings of the $4^{\text {th }}$ Biennial SGA Meeting. Balkema, Rotterdam, pp 679-682

Štemprok M, Pivec E, Langrová A (2005) The petrogenesis of a wolframite-bearing greisen in the Vykmanov granite stock, Western Krušné hory Pluton (Czech Republic). Bull Geosci 80: 163-184

Thomas HV, Large RR, Bull SW, Maslennikov V, Berry RF, Fraser R, Froud S, Moye R (2011) Pyrite and pyrrhotite textures and composition in sediments, laminated quartz veins, and reefs at Bendigo Gold Mine, Australia: insights for ore genesis. Econ Geol 106: 1-31

Tischendorf G (1989) Some conceptional aspects of the relationship between volcanism, plutonism and metallogenesis in the continental crust. Z geol Wiss 17: 553-557

Vondrovic L, Trubač J, Dobeš P, Dolejš D (2011) Origin of wolframite mineralization at Jeřmanice (central Europe): evidence from mineral chemistry, fluid inclusions and stable isotopes. In: Barra F, ReIch M, CAmpos E, Tornos F (eds) Let's Talk Ore Deposits. Proceedings of the $11^{\text {th }}$ Biennial SGA Meeting. Ediciones Universidad Catolica del Norte, Antofagasta, pp 225-227

Vondrovic L, Klomínský J, BŘízová, E, Buriánek D, HaVlíček P, Kachlík V, Košuličová M, Malík J, Martínek K, Pecina V, Rambousek P, Rapprich V, Rukavičková L, Sidorinová T, Skácelová D, Skácelová Z, Štor T, Vrána S, Verner K (2015) Explanations to basic geologic map of the Czech Republic 1:25 000, sheet 03-141 Raspenava. Unpublished manuscript, Czech Geological Survey, Prague, pp 1-202 (in Czech with English abstract)

Watznauer A (1940) Metamorphe Greisen, ein Beitrag zur Frage kaledonischer Zinnerzlagerstätten in den Sudeten. Firgenwald 12: 152-154

Žák J, Verner K, Sláma J, Kachlík V, Chlupáčová M (2013) Multistage magma emplacement and progressive strain accumulation in the shallow-level Krkonoše-Jizera Plutonic Complex, Bohemian Massif. Tectonics, 32: 1493-1512. doi:10.1002/tect.20088 